\title{
THE EFFECT AT MUSCLE POWER ARM, HAND-EYE COORDINATION, FLEXIBILITY AND SELF CONFIDENCE UPON BADMINTON SMASH SKILL
}

\author{
Myrza Akbari ${ }^{1}$, Firmansyah Dlis $^{2}$, Widiastuti ${ }^{3}$ \\ State University of Jakarta ${ }^{1}$ \\ State University of Jakarta ${ }^{2}$ \\ State University of Jakarta ${ }^{3}$ \\ myrza.ab@gmail.com
}

\begin{abstract}
This study aims to reveal whether there is effect muscle power arm, hand eye coordination, flexibility and confidence to smash badminton skills, either directly or indirectly. The research was conducted at the Serambi Mekkah University, with a sample consisting of 73 samples were selected from 677. physical education, health and recreation students, serambi mekkah university of Banda Aceh". The analysis technique used in this research is using path analysis (path analysis), with the aim to identify the direct and indirect effect between variables. The results showed that: (1) Arm muscle power directly effect the confidence of 4.62\%, (2) Hand-eye coordination has a direct effect on confidence of 59.29\%. (3) Flexibility of the torso indirectly effect the confidence of 92.69\%, (4) Arm muscle power indirectly effect badminton smash skills of 66.55\%. (5) Eye-hand coordination directly effects badminton smash skills by $8.64 \%$, (6) Flexibility of the torso directly effects badminton smash skills by $10.43 \%$, (7) Confidence directly effects badminton smash skills of $14.90 \%$.
\end{abstract}

Keywords: Badminton smash skills, muscle power arm, hand-eye coordination, flexibility, confident

Badminton in Indonesia has placed itself as a sport that is very popular among the public, badminton is Indonesia's flagship sport in multieven event because of the achievements achieved and able to compete with other countries in the world. Consequences of achievements that have been achieved is every player is required to always achieve optimal performance. Accordingly, both players and coaches are required to implement a pattern of scientific training programs in accordance with the current development of the sport. The process of coaching in badminton cannot be done instantly, but must go through a long process. To achieve the optimal performance required various supporting variables such as physical factors and psychological factors, but it also required perseverance, sacrifice, determination and based on high motivation for optimal achievement.

Badminton is a sport that requires players / athletes to have elements of physical condition that some of them are like power, coordination and flexibility, and excellent physical endurance. In addition, this sport should also be supported by mental factors, because it is no secret that the current psychic element becomes an important factor to support the skills of exercise.

Badminton is one of the courses that students studied in the course of Physical Education, Health and Recreation Serambi Mekkah University of Banda Aceh. In this course students learn the basic techniques of badminton games that match the rules of badminton play is good and true, which will be applied when teaching in school or when serving in the community.

In badminton lectures, the core activities of the lectures are various physical movement activities arranged in a motion pattern to perform various basic techniques of badminton skills. Through such diverse physical movement activities students are expected to experience the motion, which in turn will lead to changes in skilled behavior that can be observed and measured as a skill. Activity movement in learning badminton in the form of mastery of various basic skills such as badminton badge (strokes), which includes lob, long service, and smash. 
In badminton, smash is a kind of punch that is usually used to turn off the opponent and to gain points. Smash is one of the punch techniques in badminton that requires flexibility in moving. To be able to smash well, a badminton player must be equipped with good motion and mental factors. Smash skills occur because of a series of systematic movements. The basic technique of performing smash skills begins by pulling the right leg backward, the position of the left shoulder facing the opponent, the weight is on the right foot, the left hand is lifted to keep the balance. The movement begins by moving the weight from the right foot to the left foot while turning the right shoulder to the right, along with it swinging the right arm holding the racket ends with a cross to the bottom of the body.

Usman explains that the definition of smash is to strike a ball of forehand or a very loud and sharp backhand or full smash, because it is accompanied by all the energy available, and more so with a jump that aims to press the opponent until the ball turns off. Basically the forehand smash movement is the same as the throwing movement, the stages of smash movements that start from the preparation, the implementation to the followtrought are arranged in sequence, the sequential muscle action (kinetic chain) often occurs in the movement with the principle of throwing, this principle involves the recruitment of body segments into in motion at the right time, Movement generally uses large muscle groups.

Power or speed is the ability to resist resistance / burden with rapid and explosive movements. This restriction refers to the ability to move quickly, so that when the resistance is unable to move quickly then the force of speed will turn into an explosive force. Power is the primary key for the final quality of a smash. so, at the time of a smash hit, there is a muscle performance that is: elasticity at the time of releasing a punch.

Coordination is the body's ability to integrate different movements into a single, harmonious and effective movement. In badminton games, the time required to process visual information can be an important factor to distinguish the performance of badminton players from each other.

Smash motion is a body activity that harnesses the power of the arm muscle swing and is assisted with other body movements, resulting in a strong and hard punch. The swing arm movement combined with good flexibility will result in a good smash hit too. So badminton players to reach the highest level requires strength, stamina and flexibility.

Confidence can play a major role in determining success in life. It is further disclosed that, confidently determines someone dare to take risks. If a person has enough self-confidence in his ability, he will be sure that something wrong is done, he is able to correct it. Exercise is instrumental in developing a positive self-image and self-confidence. Confidence can trigger motivation and increase one's self-esteem, achievement motivation and self-esteem are important characteristics for achievement of sports achievement.

Based on the description above, it is assumed that arm muscle power factor, hand-eye coordination, Flexibility of the torso and confidence are the factors that effect badminton smash skills.

On the other hand, based on preliminary observations, the authors identified that students' badminton smash skills in the Penjekesrek Program Serambi Mekkah University of Banda Aceh were relatively poor, presumably caused by variables such as arm muscle power, hand-eye coordination, Flexibility of the torso and confidence, based on this, it is necessary to hold a scientific approach to see the effect of the above variables by doing a research. so it is relevant the author makes research with the theme of arm muscle power, eye-hand coordination, the formation of Flexibility of the torso and self-confidence and its effect on smash badminton skills students in the in the Penjekesrek Program Serambi Mekkah University of Banda Aceh.

In general, this study aims to identify the effect of arm muscle power, hand eye coordination, flexibility of the torso and confidence in badminton smash skills, either directly or indirectly. 


\section{METHOD}

The variables in this study are endogenous variables, ie badminton smash skills (Y), second variable is intervening variable, ie self confidence $\left(\mathrm{X}_{4}\right)$, and third variable is exogenous variable consisting of arm muscle power $\left(\mathrm{X}_{1}\right)$, eye-hand coordination $\left(\mathrm{X}_{2}\right)$ and flexibility of the torso $\left(\mathrm{X}_{3}\right)$ constellations:

. The path analysis model (path analisys) in this study can be seen in the following

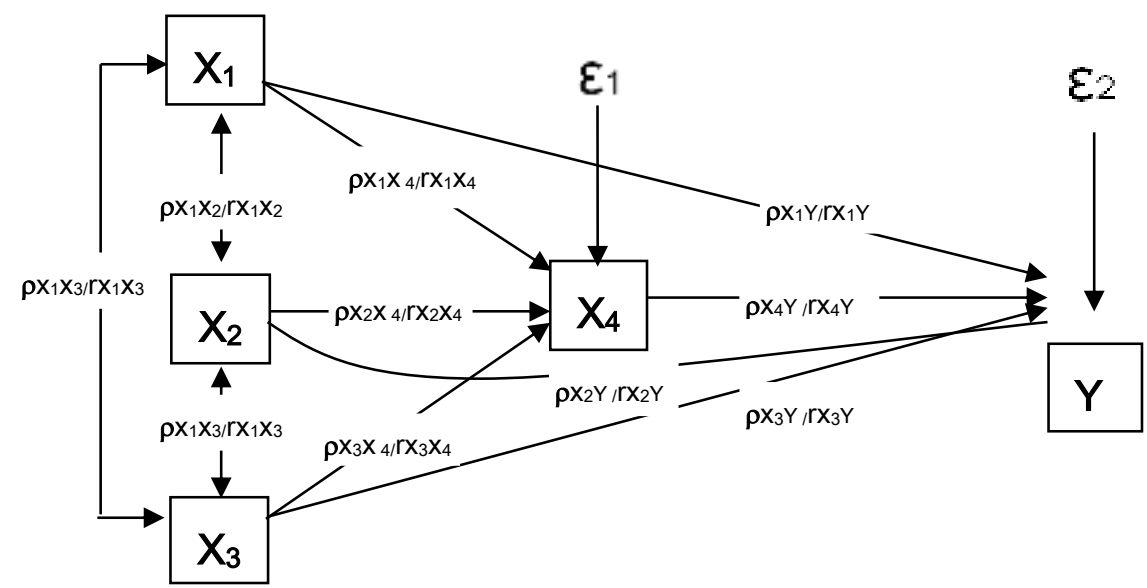

Causality Relationship of Path Coefficients

$\mathrm{X}_{1} \quad$ : Arm muscle power

$\mathrm{X}_{2} \quad$ : Hand-eye Coordination

$\mathrm{X}_{3} \quad$ : Flexibility of the torso

$\mathrm{X}_{4} \quad$ : Confidence

Y : Badminton smash skills

$\rho \mathrm{x}_{1} \mathrm{x}_{4} \quad$ : Path coefficient variable $\mathrm{X}_{1}$ to variable $\mathrm{X}_{4}$

$\rho \mathrm{x}_{2} \mathrm{X}_{4}$ : Path coefficient variable $\mathrm{X}_{2}$ to variable $\mathrm{X}_{4}$

$\rho \mathrm{x}_{3} \mathrm{x}_{4}$ : Path coefficient variable $\mathrm{X}_{3}$ to variable $\mathrm{X}_{4}$

$\rho \mathrm{x}_{1} \mathrm{Y}$ : Path coefficient variable $\mathrm{X}_{1}$ to variable $\mathrm{Y}$

$\rho \mathrm{x}_{2} \mathrm{Y}$ : Path coefficient variable $\mathrm{X}_{2}$ to variable $\mathrm{Y}$

$\rho \mathrm{x}_{3} \mathrm{Y}$ : Path coefficient variable $\mathrm{X}_{3}$ to variable $\mathrm{Y}$

$\rho \mathrm{x}_{4} \mathrm{Y}$ : Path coefficient variable $\mathrm{X}_{4}$ to variable $\mathrm{Y}$

$\mathrm{rx}_{1} \mathrm{X}_{2}$ : corelation coefficient variable $\mathrm{X}_{1}$ to variable $\mathrm{X}_{2}$

$\mathrm{rx}_{3} \mathrm{X}_{2}$ : corelation coefficient variable $\mathrm{X}_{3}$ to variable $\mathrm{X}_{2}$

The population of this study are students of physical education, health and recreation students, serambi mekkah university of Banda Aceh" academic year 2014/2015 which amounted to 677 people. purposive sampling technique that determines the sample with certain considerations, for example by considering the ability possessed by the sample. In this connection the samples that researchers will take for instrument testing and research data collection are students who are proficient and able to perform smash techniques from 677 students who are identified based on the results of smash badminton tests on students of physical education, health and recreation students, serambi mekkah university of Banda Aceh conducted at the time preliminary observation. so that 30 samples were identified for the test (the test sample should not be included in the research data collection) and 73 samples for the collection of research data.

In this study, the instruments used in collecting data used based on the variables involved are described as follows:

1. Badminton Smash Skill Test Instrument 
Instrument test of smash skills in badminton game is the total score of a person's ability when doing smashs by performing the appropriate body movements in accordance with the technique of doing good smash badminton and true with 4 dimensions based on preparation, swinging racket to back, swinging racket forward and implementation with 12 indicators, the indicator will then be given the following assessment, as follows; 4 = Very Good, 3 = Good, $2=$ Enough, $1=$ Less.

2. Arm Muscle Power Test Instrument

The test instrument of arm muscle power capability is the score obtained from the maximum muscle-deployment test at maximum speed when releasing the load / resistance in the form of a bullet towards the front with rapid and explosive movement. The unit of measurement used to identify this test is meter $(\mathrm{m})$.

3. Eye-Hand Coordination Test Instrument

The eye-hand coordination test instrument is a total score of ability to control the movement of a muscle from one pattern of movement to the next pattern of movement appropriately through the integration of the eyes and hands during the throwing of a tennis ball with one hand and recapture with a different hand over 15 seconds.

4. Flexibility Of The Torso Test Instrumen

Flexibility of the torso test instrumen is the score of the ability of space owned joints with the movement of joints to the maximum in accordance with the possibility of movement (range of movement) at the time of motion of floating from the floor to the maximum awkward ability.Some people who have wide joint space will have a kelentukan which is good, the test is very relevant to the movement of body when making a smash.

5. Confidence Test Instrumen

Confident instrument is a score obtained through a Likert questionnaire with 54 points statement based on indicators of confidence, namely (1) Awareness of strengths / advantages possessed, (2) Awareness of weaknesses / shortcomings possessed, (3) Ability (4) Ability to accept failure objectively, (5) Awareness of successes and failures experienced, (6) Ability to determine the feelings that are consistent with the condition of self, (7) Understanding of the factors that support achievement of goals, and (8) Ability to determine what should be done to achieve the target The definition and indicators will be a reference in making the items.

Data analysis techniques used are as follows:

1. Descriptive statistics, namely statistics that aims to provide data description of each research variable.

2. Test analysis requirements that include (1) data normality test, and (2) linearity test.

3. Correlation statistics, to see the relationships that occur between exogenous variables and endogenous variables that are related to each other.

4. Path analysis, to see the effect of a variable on other variables.

\section{RESULTS}

Furthermore, the exposure of some descriptive statistics starts from $\mathrm{Y}$ and then proceeds with variables $\mathrm{X}_{1}, \mathrm{X}_{2}, \mathrm{X}_{3}$ and $\mathrm{X}_{4}$.

Descriptions of Research Results

\begin{tabular}{|l|c|c|c|c|c|c|c|c|c|c|}
\hline \multirow{3}{*}{ Statistic } & \multicolumn{10}{|c|}{ Variable } \\
\cline { 2 - 11 } & \multicolumn{2}{|c|}{$\begin{array}{c}\text { Badminton } \\
\text { smash skills }\end{array}$} & \multicolumn{2}{c|}{$\begin{array}{c}\text { Arm muscle } \\
\text { power }\end{array}$} & \multicolumn{2}{c|}{$\begin{array}{c}\text { Hand-eye } \\
\text { Coordination }\end{array}$} & \multicolumn{2}{c|}{$\begin{array}{c}\text { Flexibility of } \\
\text { the torso }\end{array}$} & \multicolumn{2}{c|}{ Confidence } \\
\cline { 2 - 11 } & $\begin{array}{c}\text { Default } \\
\text { score }\end{array}$ & $\begin{array}{c}\mathrm{Z} \\
\text { score }\end{array}$ & $\begin{array}{c}\text { Default } \\
\text { score }\end{array}$ & $\begin{array}{c}\mathrm{Z} \\
\text { score }\end{array}$ & $\begin{array}{c}\text { Default } \\
\text { score }\end{array}$ & $\begin{array}{c}\mathrm{Z} \\
\text { score }\end{array}$ & $\begin{array}{c}\text { Default } \\
\text { score }\end{array}$ & $\begin{array}{c}\mathrm{Z} \\
\text { score }\end{array}$ & $\begin{array}{c}\text { Default } \\
\text { score }\end{array}$ & $\begin{array}{c}\mathrm{Z} \\
\text { score }\end{array}$ \\
\hline $\begin{array}{l}\text { Maximum } \\
\text { Value }\end{array}$ & 41 & 1,602 & 8,66 & 1,456 & 19 & 1,591 & 71,30 & 1,954 & 254 & 1,314 \\
\hline
\end{tabular}




\begin{tabular}{|l|c|c|c|c|c|c|c|c|c|c|}
\hline $\begin{array}{l}\text { Minimum } \\
\text { Value }\end{array}$ & 31 & $-2,530$ & 4,87 & $-1,628$ & 9 & $-2,267$ & 44,45 & $-1,757$ & 158 & $-2,467$ \\
\hline Average & 37,12 & 1,118 & 6,87 & 1,164 & 14,88 & 1,001 & 57,16 & 1,177 & 220,64 & 1,006 \\
\hline Range & 10 & 4,131 & 3,79 & 3,084 & 10 & 3,857 & 26,85 & 3,711 & 96 & 3,781 \\
\hline $\begin{array}{l}\text { Standard } \\
\text { deviation }\end{array}$ & 1,602 & 1,602 & 1,510 & 1,456 & 2,592 & 1,591 & 7,235 & 1,954 & 25,392 & 1,314 \\
\hline N & \multicolumn{2}{|c|}{73} & \multicolumn{2}{|c|}{73} & \multicolumn{2}{|c|}{73} & \multicolumn{2}{c|}{73} & \multicolumn{2}{c|}{73} \\
\hline
\end{tabular}

Based on the results of the path coefficients in sub-structures 1 and sub-structure 2, an overall causal relationship between $\mathrm{X}_{1}, \mathrm{X}_{2}, \mathrm{X}_{3}$, and $\mathrm{X}_{4}$ may be described as follows:

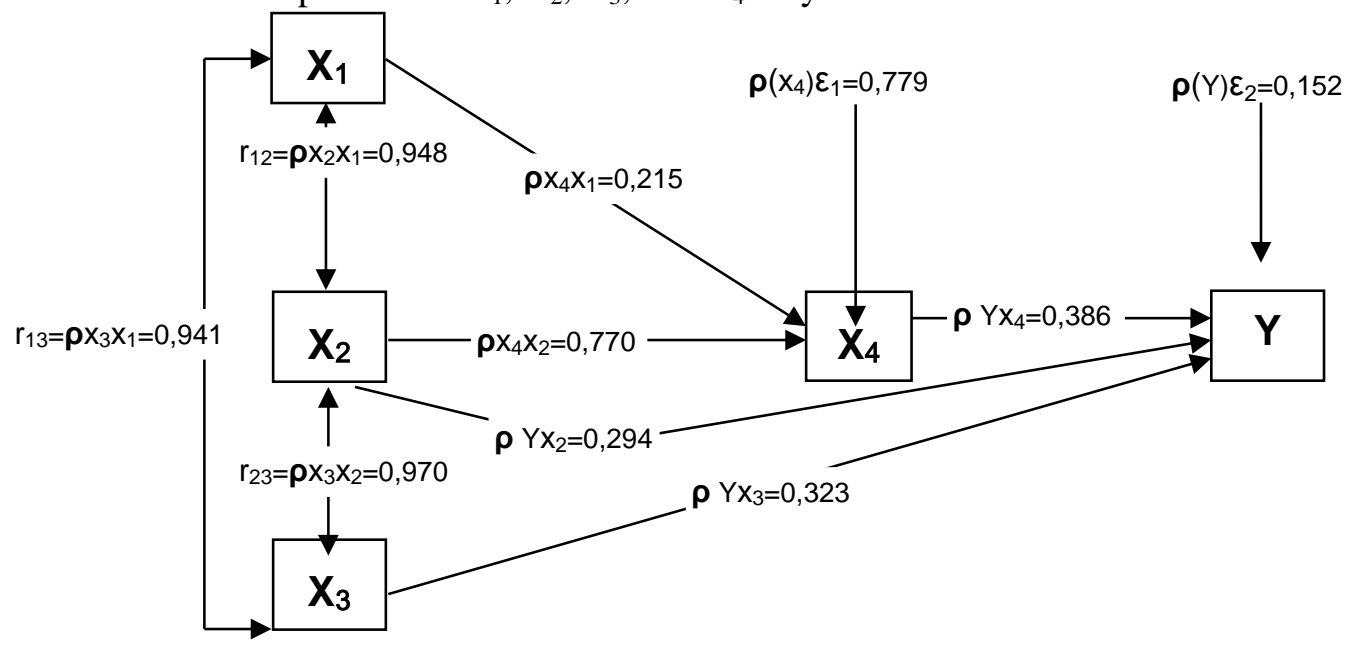

Causal Relation of variables $\mathrm{X}_{1}, \mathrm{X}_{2}, \mathrm{X}_{3}$, and $\mathrm{X}_{4}$ against $\mathrm{Y}$

The results of the path coefficients in sub-structures 1 and sub-structure 2 turn into structural equations, as follows:

a. Sub-structure 1:

$$
\begin{aligned}
& \mathrm{X}_{4}=\rho \mathrm{X}_{4} \mathrm{X}_{1} \mathrm{X}_{1}+\rho \mathrm{x}_{4} \mathrm{X}_{2} \mathrm{X}_{2}+\varepsilon_{1} \text { and } \mathrm{R}^{2} \mathrm{X}_{4} \mathrm{X}_{2} \mathrm{X}_{1} \\
& \mathrm{X}_{4}=0,215 \mathrm{X}_{1}+0,770 \mathrm{X}_{2}+0,799 \varepsilon_{1} \text { and } \mathrm{R}^{2} \mathrm{X}_{4} \mathrm{X}_{2} \mathrm{X}_{1}=0,952
\end{aligned}
$$

b. Sub-structure 2:

$$
\begin{aligned}
& Y=\rho \mathrm{Yx}_{2} \mathrm{x}_{2}+\rho \mathrm{Yx}_{3} \mathrm{x}_{3}+\rho \mathrm{Yx}_{4} \mathrm{x}_{4}+\varepsilon_{1} \text { and } \mathrm{R}^{2} \mathrm{Yx}_{4} \mathrm{x}_{3} \mathrm{x}_{2} \\
& \mathrm{Y}=0,294 \mathrm{X}_{2}+0,323 \mathrm{X}_{3}+0,386 \mathrm{X}_{4}+0,152 \varepsilon_{2} \text { and } \mathrm{R}^{2} \mathrm{Yx}_{4} \mathrm{x}_{3} \mathrm{X}_{2}=0,977
\end{aligned}
$$

\section{Hypothesis Testing}

After testing the model, then tested the hypothesis to determine the direct and indirect effects between variables. The proposed hypothesis will be concluded through the calculation of path coefficient and significance for each path under study. The result of the decision on all hypotheses proposed, described as follows.

a. Arm muscle power $\left(\mathrm{X}_{1}\right)$ Effect Directly To Self Confidence $\left(\mathrm{X}_{4}\right)$

Hypothesis testing is performed to prove that arm muscle power $\left(\mathrm{X}_{1}\right)$ has direct effect on Confidence $\left(\mathrm{X}_{4}\right)$. The hypotheses tested are as follows:

$$
\begin{aligned}
& \mathrm{H}_{0}: \rho_{\mathrm{X} 4 \mathrm{X} 1}=0 \\
& \mathrm{H}_{0}: \rho_{\mathrm{X} 4 \mathrm{X} 1}>0
\end{aligned}
$$

Based on the above data analysis, the coefficient value of $X_{1}$ to $X_{4}\left(\rho X_{4} X_{1}\right)$ is 0.215 where the $t$ count is 2.594 , then at $\alpha=0,05$ obtained by t table 2,290 . Thus it is identified that the $t$ count (2.594) is greater than the $t$ table $(2,290)$, so the path coefficient is significant. So based on these calculations found that arm muscle power $\left(\mathrm{X}_{1}\right)$ directly effect the confidence $\left(\mathrm{X}_{4}\right)$.

b. Hand-eye Co-ordination $\left(\mathrm{X}_{2}\right)$ Directly Effects Self-Confidence $\left(\mathrm{X}_{4}\right)$

Hypothesis testing is performed to prove that hand-eye coordination $\left(\mathrm{X}_{2}\right)$ has a direct effect on Confidence $\left(\mathrm{X}_{4}\right)$. The hypotheses tested are as follows: 


$$
\begin{aligned}
& \mathrm{H}_{0}: \rho_{\mathrm{X} 4 \mathrm{X} 2}=0 \\
& \mathrm{H}_{0}: \rho_{\mathrm{X} 4 \mathrm{X} 2}>0
\end{aligned}
$$

Based on the above data analysis, the coefficient value of $X_{2}$ to $X_{4}\left(\rho X_{4} X_{2}\right)$ is 0,770 where $t$ count is 9,305 , then at $\alpha=0,05$ obtained by t table 2,290. So it is identified that the value of $t$ count $(9,305)$ is greater than the $t$ table value $(2,290)$, so the path coefficient is significant. So based on these calculations found that hand-eye coordination $\left(\mathrm{X}_{2}\right)$ has a direct effect on Confidence $\left(\mathrm{X}_{4}\right)$.

c. Flexibility of the torso $\left(\mathrm{X}_{3}\right)$ Directly Effects Self-Confidence $\left(\mathrm{X}_{4}\right)$

Hypothesis testing is performed to prove that flexibility the torso $\left(\mathrm{X}_{3}\right)$ has a direct effect on self-confidence $\left(\mathrm{X}_{4}\right)$. The hypotheses tested are as follows:

$$
\begin{aligned}
& \mathrm{H}_{0}: \rho_{\mathrm{X} 4 \mathrm{X} 3}=0 \\
& \mathrm{H}_{0}: \rho_{\mathrm{X} 4 \mathrm{X} 3}>0
\end{aligned}
$$

Based on the above data analysis, the coefficient value of $X_{3}$ to $X_{4}\left(\rho X_{4} X_{3}\right)$ is equal to -0.317 where the value of $t$ count is -2.993 , then at $\alpha=0.05$ obtained $t$ table of 2,290 . So it is identified that the value of $t$ count $(-2.993)$ is smaller than the $t$ table value $(2,290)$, so the path coefficient is not significant. So based on the calculations found that the flexibility of the torso $\left(\mathrm{X}_{3}\right)$ has no direct effect on Confidence $\left(\mathrm{X}_{4}\right)$.

d. Arm muscle power $\left(\mathrm{X}_{1}\right)$ Effect Directly to Badminton Smash Skill (Y)

Hypothesis testing is performed to prove that arm muscle power $\left(\mathrm{X}_{1}\right)$ directly effect the skills of smash badminton $(\mathrm{Y})$. The hypotheses tested are as follows:

$$
\begin{aligned}
& \mathrm{H}_{0}: \rho_{\mathrm{YX} 1}=0 \\
& \mathrm{H}_{0}: \rho_{\mathrm{YX} 1}>0
\end{aligned}
$$

Based on the data analysis above obtained the coefficient of $\mathrm{X}_{1}$ to $\mathrm{Y}\left(\rho \mathrm{YX}_{1}\right)$ is 0.109 where the value of $t$ count is 1.696 , then at $\alpha=0.05$ obtained $t$ table of 2,290 . So it is identified that the value of $t$ count (2.594) is smaller than the $t$ table value $(2,290)$, so the path coefficient is not significant. So based on the calculations found that arm muscle power $\left(\mathrm{X}_{1}\right)$ has no direct effect on badminton smash skills (Y).

e. Hand-eye Co-ordination $\left(\mathrm{X}_{2}\right)$ Effects Directly to Badminton Smash Skills (Y)

Hypothesis testing is performed to prove that Eye-hand coordination $\left(\mathrm{X}_{2)}\right.$ has direct effect on badminton smash (Y) skill. The hypotheses tested are as follows:

$$
\begin{aligned}
& \mathrm{H}_{0}: \rho_{\mathrm{YX} 2}=0 \\
& \mathrm{H}_{0}: \rho_{\mathrm{YX} 2}>0
\end{aligned}
$$

Based on the above data analysis, the coefficient value of $\mathrm{X}_{2}$ path to $\mathrm{Y}\left(\rho \mathrm{YX}_{2}\right)$ is 0.294 where the $\mathrm{t}$ count value is 1.696 , then at $\alpha=0.05$ obtained $t$ table of 2,290 . So it is identified that the value of $t$ count $(0.294)$ is greater than the $t$ table value $(2,290)$, so the path coefficient is significant. So based on these calculations it was found that Eye-hand coordination $\left(\mathrm{X}_{2}\right)$ had a direct effect on badminton smash skills (Y).

f. Flexibility of the torso $\left(\mathrm{X}_{3}\right)$ Directly Effects Badminton Smash Skill (Y)

Hypothesis testing is done to prove that the flexibility of the torso $\left(\mathrm{X}_{3}\right)$ directly effects the skills of smash badminton (Y). The hypotheses tested are as follows:

$$
\begin{aligned}
& \mathrm{H}_{0}: \rho_{\mathrm{YX} 3}=0 \\
& \mathrm{H}_{0}: \rho_{\mathrm{YX} 3}>0
\end{aligned}
$$

Based on the analysis above data obtained coefficient value of $\mathrm{X}_{3}$ path to $\mathrm{Y}\left(\rho \mathrm{YX}_{3}\right)$ is equal to 0.323 where the $t$ count value of 4.210 , then at $\alpha=0.05$ obtained $t$ table of 2.290 . So it is identified that the value of $t$ count (4.210) is greater than the $t$ table value $(2,290)$, so the path coefficient is significant. So based on the calculations found that the flexibility of the torso $\left(\mathrm{X}_{3}\right)$ directly effect the skills of smash badminton (Y).

g. Self Confidence $\left(\mathrm{X}_{4}\right)$ Effect Directly to Badminton Smash Skill (Y) 
Hypothesis testing is done to prove that the confidence (X4) directly effect the skills of smash badminton (Y). The hypotheses tested are as follows:

$$
\begin{aligned}
& \mathrm{H}_{0}: \rho_{\mathrm{YX} 4}=0 \\
& \mathrm{H}_{0}: \rho_{\mathrm{YX} 4}>0
\end{aligned}
$$

Based on the analysis above data obtained coefficient of $\mathrm{X}_{3}$ to $\mathrm{Y}\left(\rho \mathrm{YX}_{4}\right)$ is 0.386 where $\mathrm{t}$ count 4,772 , then at $\alpha=0,05$ obtained $t$ table equal to 2,290 . So it is identified that the $t$ count (4.772) is greater than the $t$ table $(2,290)$, so the path coefficient is significant. So based on these calculations found that confident $\left(\mathrm{X}_{4}\right)$ have direct effect on badminton smash skills $(\mathrm{Y})$.

After the results of the analysis and statistical tests of the proposed hypothesis are obtained, the results of its summary, especially those that directly effect, as shown in the table below

Table 2 Recapitulation of Hypothesis Testing Results

\begin{tabular}{|c|l|c|c|c|}
\hline No & \multicolumn{1}{|c|}{ Hypothesis } & Statistic Test & Decision $\mathrm{H}_{0}$ & Conclusion \\
\hline a. & $\begin{array}{l}\text { The arm muscle power directly } \\
\text { effects the self-confidence }\end{array}$ & $\begin{array}{c}\mathrm{H}_{0}: \rho_{\mathrm{X} 4 \mathrm{X} 1}=0 \\
\mathrm{H}_{0}: \rho_{\mathrm{X} 4 \mathrm{X} 1}>0\end{array}$ & $\mathrm{H}_{0}$ rejected & directly \\
\hline b. & $\begin{array}{l}\text { Eye-hand coordination directly } \\
\text { effects self-confidence }\end{array}$ & $\begin{array}{c}\mathrm{H}_{0}: \rho_{\mathrm{X} 4 \mathrm{X} 2}=0 \\
\mathrm{H}_{0}: \rho_{\mathrm{X} 4 \mathrm{X} 2}>0\end{array}$ & $\mathrm{H}_{0}$ rejected & directly \\
\hline d. & $\begin{array}{l}\text { Muscle flexibility directly } \\
\text { effects self-confidence }\end{array}$ & $\begin{array}{c}\mathrm{H}_{0}: \rho_{\mathrm{X} 4 \mathrm{X} 2}=0 \\
\mathrm{H}_{0}: \rho_{\mathrm{X} 4 \mathrm{X} 2}>0\end{array}$ & $\begin{array}{c}\mathrm{H}_{0} \text { be } \\
\text { accepted }\end{array}$ & Not directly \\
\hline e. & $\begin{array}{l}\text { Arm muscle power directly } \\
\text { effect badminton smash skills }\end{array}$ & $\begin{array}{c}\mathrm{H}_{0}: \rho_{\mathrm{YX} 1}=0 \\
\mathrm{H}_{0}: \rho_{\mathrm{YX} 1}>0\end{array}$ & $\begin{array}{c}\mathrm{H}_{0} \text { be } \\
\text { accepted }\end{array}$ & Not directly \\
\hline f. & $\begin{array}{l}\text { Eye-hand coordination directly } \\
\text { effects badminton smash skills }\end{array}$ & $\begin{array}{l}\mathrm{H}_{0}: \rho_{\mathrm{YX} 2}=0 \\
\mathrm{H}_{0}: \rho_{\mathrm{YX} 2}>0\end{array}$ & $\mathrm{H}_{0}$ rejected & Not directly \\
\hline g. & $\begin{array}{l}\text { Muscle flexibility directly } \\
\text { effects badminton smash skills }\end{array}$ & $\begin{array}{l}\mathrm{H}_{0}: \rho_{\mathrm{YX} 3}=0 \\
\mathrm{H}_{0}: \rho_{\mathrm{YX} 3}>0\end{array}$ & $\mathrm{H}_{0}$ rejected & directly \\
\hline h. & $\begin{array}{l}\text { Confidence directly effects the } \\
\text { skills of smash badminton }\end{array}$ & $\begin{array}{l}\mathrm{H}_{0}: \rho_{\mathrm{YX} 4}=0 \\
\mathrm{H}_{0}: \rho_{\mathrm{YX} 4}>0\end{array}$ & $\mathrm{H}_{0}$ rejected & directly \\
\hline
\end{tabular}

\section{DISCUSSION}

Based on the test results from a hypothesis that has been done in the hypothesis testing section, it can be stated that:

First, for hypothesis there is significant effect of arm muscle power $\left(\mathrm{X}_{1}\right)$, hand-eye coordination $\left(\mathrm{X}_{2}\right)$, flexibility of torso $\left(\mathrm{X}_{3}\right)$ to self-confidence $\left(\mathrm{X}_{4}\right)$ after hypothesis testing individually obtained variable of flexibility of torso $\left(\mathrm{X}_{3}\right)$ its effect on confidence $\left(\mathrm{X}_{4}\right)$. Based on the results of hypothesis testing with path analysis obtained that there is positive effect of arm muscle power $\left(\mathrm{X}_{1}\right)$ and hand-eye coordination $\left(\mathrm{X}_{2}\right)$ to confidence $\left(\mathrm{X}_{4}\right)$. The structural equation of path analysis results from arm muscle power $(\mathrm{X} 1)$ and hand-eye coordination $\left(\mathrm{X}_{2}\right)$ to confidence $\left(\mathrm{X}_{4}\right)$ is $\mathrm{X}_{4}=0.215 \mathrm{X}_{1}+$ $0.770 \mathrm{X}_{2}+0.799 \varepsilon 1$. While the contribution $\left(\mathrm{X}_{2}, \mathrm{X}_{3}\right.$ and $\left.\mathrm{X}_{4}\right)$ simultaneously to $\mathrm{Y}$ equal to 0.952 or $95.2 \%$ which means that $95.2 \%$ confidence variation $\left(\mathrm{X}_{4}\right)$ is effect by variation of arm muscle power $\left(\mathrm{X}_{1}\right)$ and hand-eye coordination $\left.\left(\mathrm{X}_{2}\right)\right)$.

Second, for hypothesis there are significant effect of arm muscle power $\left(\mathrm{X}_{1}\right)$, hand-eye coordination $\left(\mathrm{X}_{2}\right)$, flexibility of body $\left(\mathrm{X}_{3}\right)$ and self-confidence $\left(\mathrm{X}_{4}\right)$ against badminton smash $(\mathrm{Y})$ skill, after hypothesis testing individually obtained variable arm muscle power $\left(\mathrm{X}_{1}\right)$ does not significantly effect its badminton smash (Y) skills. Based on the results of hypothesis testing with path analysis obtained that there are positive effects of hand-eye coordination $\left(\mathrm{X}_{2}\right)$, flexibility of body $\left(\mathrm{X}_{3}\right)$ and selfconfidence $\left(\mathrm{X}_{4}\right)$ against badminton smash $(\mathrm{Y})$ skills. The structural equation of path analysis result from hand-eye coordination $\left(\mathrm{X}_{2}\right)$, flexibility of the torso $\left(\mathrm{X}_{3}\right)$ and self-confidence $\left(\mathrm{X}_{4}\right)$ to badminton smash ( $\mathrm{Y})$ is $\mathrm{Y}=0,294 \mathrm{X}_{2}+0,323 \mathrm{X}_{3}+0,386 \mathrm{X}_{4}+0,152 \varepsilon 2$. While the contribution of $\mathrm{X}_{1}$ and $\mathrm{X}_{2}$ simultaneously to $\mathrm{X}_{4}$ is 0,977 or $97,7 \%$ which means that $97,7 \%$ variation of badminton smash (Y) 
skill is effect by variation of hand-eye coordination $\left(\mathrm{X}_{2}\right)$, flexibility of the torso $\left(\mathrm{X}_{3}\right)$ and confident $\left(\mathrm{X}_{4}\right)$.

These findings indicate that to improve the skills of smash badminton (Y), it is necessary to consider and increase the variables of arm muscle power $\left(\mathrm{X}_{1}\right)$, hand-eye coordination $\left(\mathrm{X}_{2}\right)$, flexibility of the torso $\left(\mathrm{X}_{3}\right)$ and confident $(\mathrm{X} 4)$.

\section{CONCLUSIONS}

Based on the results of the analysis on the variables of badminton smash skills (Y), arm muscle power $\left(\mathrm{X}_{1}\right)$, hand-eye coordination $\left(\mathrm{X}_{2}\right)$, flexibility of the torso $\left(\mathrm{X}_{3}\right)$ and confidence $\left(\mathrm{X}_{4}\right)$, can be concluded that:

1. Arm muscle power directly effect the confidence of $4.62 \%$.

2. Hand-eye coordination has a direct effect on confidence of $59.29 \%$.

3. Flexibility of the torso indirectly effect the confidence of $92.69 \%$.

4. Arm muscle power indirectly effect badminton smash skills of $66.55 \%$.

5. Eye-hand coordination directly effects badminton smash skills by $8.64 \%$.

6. Flexibility of the torso directly effects badminton smash skills by $10.43 \%$.

7. Confidence directly effects badminton smash skills of $14.90 \%$.

\section{REFERENCE}

Tumin, Atmadi Usman. (2011). Kejar Bulutangkis, Jakarta: PT. Rineka Cipta.

Roger Bartlett. (2005). Sports Biomechanics: Reducing Injury and Improving Performance, Canada: Simultaneously published.

Lumintuarso, Ria. (2013). Teori Kepelatihan Olahraga. Jakatra; Kementerian Pemuda dan Olahraga.

Zhao Zhang. (2016). The effect of X-factor (trunk rotation) and experience on the quality of the badminton forehand smash, Journal of Human Kinetics volume 53, Hukin.

Mutohir, Toho Cholik dan Maksum, Ali. (2007). Sport Development Index. Jakarta. PT. Indeks.

Loureiro, Luiz de Franca Bahia, et, al. (2016). Development of an Agility Test for Badminton Players and Assessment of Its Validity and Test-Retest Reliability, International Journal of Sports Physiology and Performance, Volume 11, Human Kinetics.

Gabriela, Milon Alexandra. (2015). Study Regarding the Complexity of Physical Training in Badminton, Scientific Journal of Education, Sports, and Health, Volume 15, Gymnasium.

Giriwijoyo. Sentosa dan Sidik. Dikdik Zafar. (2013). Ilmu Kesehatan Olahraga. Bandung; PT. Remaja Rosdakarya.

Eylem Gencer. (2010). The Relationship Between Locus of Control, Self-Esteem and Goal Orientation, Motivational Climate in Badminton Players, Journal of Physical Education and Sport/Science Movement and Health, Volume 10, Romania. 